JAMP: Jurnal Adminitrasi dan Manajemen Pendidikan Volume 1 Nomor 1 Maret 2018, Hal : 45-51

Tersedia Online di http:/journal2.um.ac.id/index.php/jamp/ ISSN $x x x x-x x x x$ (online)

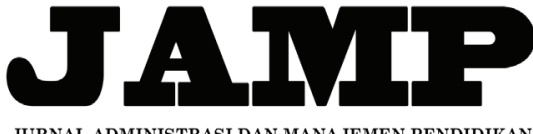

JURNAL ADMINISTRASI DAN MANAJEMEN PENDIDIKAN

\title{
LATAR MINAT \& ANIMO PESERTA DIDIK DALAM PEMBELAJARAN BERBASIS PROYEK DI SEKOLAH MENENGAH KEJURUAN 4 TAHUN
}

\author{
Hilda Novia Utomo \\ Imron Arifin \\ Agus Timan
}

\author{
email: hildanovia28@gmail.com \\ Universitas Negeri Malang, J1. Semarang No. 5 Malang 65145
}

\begin{abstract}
The focus of this research is the driving factors of students, programs and activities held, the ability obtained by learners during the education and barriers found in the implementation of 4 year school in SMK Negeri 5 Surabaya. This study uses a qualitative method. Qualitative research is a study that intends to understand the phenomenon of behavior, action, overall situation in a research subject. While the type of research used is case study research. The reason for using case studies is that this research method focuses on an intensive, detailed, and unique case. The unique case in this study is the presence of vocational schools whose education period is longer than 1 year of vocational school so that it attracts many interest of students to this school. The results of this study are the factors that encourage students to choose this school are: (a) SMK favorites in the city of Surabaya; (b) 4-year school program where practices is longer at 6-10 months; (c) A graduate of a working school; (d) The company prefers a 4 year school graduate; and (e) Many activities related to the development of students in the company. Activities undertaken by schools in the form of work programs BKK and student. These activities can improve the skills and expertise of students when graduated later, so that when working students already have supplies. The obstacles faced in the implementation of this 4 year school are the differences in the character of each learner, the presence of a less professional educator, and the presence of some equipment that has not been updated to support the learning process.
\end{abstract}

Keywords: vocational education, interest, energy

Abstrak : Fokus penelitian ini adalah faktor pendorong peserta didik, pelaksanaan program dan kegiatan sekolah, kemampuan yang diperoleh peserta didik selama menempuh pendidikan serta hambatan yang ditemukan dalam pelaksanaan sekolah 4 tahun di SMK Negeri 5 Surabaya. Penelitian ini menggunakan metode kualitatif. Penelitian kualitatif adalah penelitian yang bermaksud untuk memahami fenomena tentang perilaku, tindakan, keadaan menyeluruh pada sebuah subjek penelitian. Sedangkan jenis penelitian yang digunakan adalah penelitian studi kasus. Alasan menggunakan studi kasus adalah metode penelitian ini memusatkan perhatian pada suatu kasus yang unik secara intensif dan rinci. Kasus unik dalam penelitian ini adalah adanya sekolah kejuruan yang masa pendidikannya lebih lama 1 tahun daripada sekolah kejuruan lain sehingga menarik banyaknya minat dan animo peserta didik terhadap sekolah ini. Hasil penelitian ini yaitu faktor pendorong peserta didik memilih sekolah ini adalah: (a) SMK favorit di Kota Surabaya; (b) Program sekolah 4 tahun di mana prakerin lebih lama yaitu 6-10 bulan; (c) Lulusan sekolah yang langsung bekerja; (d) Perusahaan lebih menyukai lulusan sekolah 4 tahun; dan (e) Banyak kegiatan yang berkaitan dengan pengembangan peserta didik di perusahaan. Kegiatan yang dilaksanakan sekolah berupa program kerja BKK dan kesiswaan. Kegiatan tersebut dapat meningkatkan kemampuan dan keahlian peserta didik saat lulus nanti, sehingga saat bekerja peserta didik sudah memiliki bekal. Hambatan yang dihadapi dalam pelaksanaan sekolah 4 tahun ini yaitu perbedaan karakter setiap peserta didik dalam menerima proses pembelajaran, Pernah terdapat ada guru yang belum disiplin, dan belum lengkapnya peralatan kecil di bengkel 
karena sebagian dibawa pulang oleh peserta didik.

Kata Kunci : pendidikan kejuruan, minat, animo

Pemerintah menyelenggarakan jenjang pendidikan menengah dibagi menjadi dua yaitu, Sekolah Menengah Atas (SMA) dan Sekolah Menengah Kejuruan (SMK). Salah satu bagian dari sistem pendidikan nasional adalah pendidikan kejuruan. Pendidikan kejuruan yaitu sebuah lembaga pendidikan jenjang menengah yang memroses kemampuan peserta didik berdasarkan program keahlian yang dipilih dan mengembangkan kemampuan peserta didik sehingga menghasilkan outcome yang sesuai dengan kebutuhan DUDI/Perusahaan. Pendidikan kejuruan berfungsi untuk melatih dan meningkatkan kemampuan peserta didik dengan penekanan pada penguasaan keterampilan fungsional yang sesuai dengan kebutuhan dunia kerja. Dalam sistem pendidikan kejuruan, peserta didik selain dituntut untuk memahami pengetahuan umum juga harus mampu menerapkan dan mengasah keterampilan mereka pada jurusan yang telah dipilih, dan nantinya setelah mereka lulus dapat memilih untuk melanjutkan ke perguruan tinggi atau bekerja. Sebab tujuan pendidikan kejuruan yaitu untuk menghasilkan lulusan sekolah yang mampu beradaptasi dan siap pakai pada lingkungan kerja.

Sistem pendidikan kejuruan umumnya sama dengan sistem pendidikan di SMA yaitu masa belajarnya selama 3 tahun. Pada tahun 1969/1970, pemerintah mempunyai pemikiran untuk mengadakan pembaharuan dan perbaikan pada sistem pendidikan nasional, terutama pada Sekolah Teknologi Menengah (STM). Pembaharuan tersebut dimulai dengan Pembangunan Lima Tahun Pertama (PELITA I). Selanjutnya tahun 1970/1971, Menteri Pendidikan dan Kebudayaan menetapkan untuk menyelesaikan 8 instalasi pendidikan teknik secara bertahap yang disebut sebagai "Proyek Perintis Sekolah Teknologi Menengah Pembangunan" dengan lama belajar 4 tahun. Sejak saat itu maka di Indonesia terdapat 8 SMK yang mempunyai masa studi selama 4 tahun. Dari 8 sekolah tersebut masing-masing memiliki jurusan khas pada saat itu. Adanya sekolah kejuruan yang masa belajarnya 4 tahun berguna untuk mempersiapkan dengan matang peserta didik yang akan langsung bekerja di sebuah Dunia Usaha Dunia Industri (DUDI). Peserta didik sebagai bagian dari masyarakat yang menggunakan layanan jasa lembaga pendidikan akan dapat mengetahui dan memilih sekolah yang dapat mengembangkan keterampilan mereka lebih baik lagi dari sebelumnya. Setiap lembaga pendidikan pada dasarnya memiliki kelebihan yang dapat diunggulkan. lembaga pendidikan setiap tahunnya selalu berusaha meningkatkan pelayanan dan pemenuhan kebutuhan bagi peserta didik, salah satunya SMK Negeri 5 Surabaya. Keunikan dari sekolah kejuruan 4 tahun ini adalah pelaksanaan prakerin dilakukan pada saat kelas IV dengan lama prakerin 6-10 bulan tanpa harus memotong mata pelajaran pada saat kelas II. Keunikan inilah yang membuat SMK Negeri 5 Surabaya menjadi sekolah yang dikenal memiliki mutu lulusan yang mudah mendapatkan pekerjaan. Selain itu, minat dan animo peserta didik yang mendaftar di sekolah ini setiap tahunnya selalu mengalami kenaikan. Calon peserta didik mengetahui jika lama sekolah di SMK Negeri 5 Surabaya adalah 4 tahun tetapi tidak mengurangi antusias mereka dalam memilih sekolah ini. Kelebihan lain dalam sekolah 4 tahun ini ialah peserta didik mendapatkan pengalaman dan pengetahuan yang lebih luas daripada sekolah 3 tahun, selain itu dijelaskan bahwa nantinya lulusan sekolah ini akan dicarikan tempat bekerja oleh sekolah dan dapat langsung bekerja setelah melaksanakan prakerin jika perusahaan menyukai kinerjanya karena berdasarkan fakta banyak perusahaan yang menyetujui jika SMK Negeri 5 Surabaya melaksanakan program belajar selama 4 tahun.

\section{METODE}

Pendekatan yang digunakan dalam penelitian ini adalah pendekatan kualitatif, jenis penelitian studi kasus. Penelitian ini bermaksud untuk mengetahui secara mendalam kegiatan pembelajaran yang dilaksanakan di SMK Negeri 5 Surabaya sehingga dapat menarik animo dan minat peserta didik untuk memilih bersekolah di SMK Negeri 5 Surabaya walau lebih lama 1 tahun dari sekolah lain. Alasan menggunakan studi kasus yaitu memusatkan perhatian pada suatu kasus yang unik secara intensif dan rinci. Sumber data dalam penelitian ini yaitu Kepala Sekolah, Waka Humas, Waka Kesiswaan, Waka 
Kurikulum, Ketua BKK, peserta didik, alumni SMK Negeri 5 Surabaya dan orangtua peserta didik. Waka Humas sebagai informan kunci terkait sistem pembelajaran 4 tahun. Pengumpulan data dilakukan dengan menggunakan teknik wawancara, observasi, dan dokumentasi. Analisis data dilakukan sejak sebelum peneliti memasuki lapangan, selama di lapangan dan setelah selesai di lapangan. Analisis data dilaksanakan bersamaan dengan pengumpulan data. Dalam analisis data, peneliti mereduksi data yang telah didapatkan lalu memilah setiap data sesuai fokus dan selanjutnya membuat kesimpulan pada masing-masing temuan fokus. Setelah proses analisis data maka dilanjutkan dengan pemeriksaan keabsahan temuan informasi menggunakan teknik triangulasi (sumber, metode/teknik, dan waktu), pengecekan anggota, perpanjangan waktu pengamatan, dan kecukupan bahan referensi.

\section{HASIL}

Faktor pendorong peserta didik memilih SMK Negeri 5 Surabaya yaitu: (1) SMK favorit di Kota Surabaya; (2) Program sekolah 4 tahun di mana prakerin lebih lama yaitu 6-12 bulan; (3) Lulusan sekolah yang langsung bekerja; (4) Perusahaan lebih menyukai lulusan sekolah 4 tahun; dan (5) Banyak kegiatan yang berkaitan dengan pengembangan peserta didik di perusahaan: Muatan lokal yang ditambahkan, tambahan jam di bengkel, peralatan praktik yang cukup lengkap, luasnya lingkungan sekolah, dan materi yang didapat lengkap.

Program dan kegiatan di SMK Negeri 5 Surabaya meliputi: (1) Program kerja BKK; dan (2) Program kerja kesiswaan. Program kerja BKK mencakup seluruh kegiatan yang berkaitan dengan dunia kerja dan lulusan, program kerjanya sebagai berikut: (a) Rapat koordinasi tim BKK; (b) Mengagendakan surat dari industri; (c) Pemetaan DUDI/Rekanan, (d) Pendataan siswa kelas IV, (e) Mendatangkan narasumber dari Depnaker/DUDI; (f) Tes pemetaan psikologi (tes bakat dan minat); (g) Pembekalan siswa menuju dunia kerja workshop dan FGD; (h) Penelusuran rencana alumni; (i) Promosi dan penelusuran tamatan; (j) Pelaksanaan open recruitment di sekolah; dan (k) Pendataan alumni yang belum bekerja. Sedangkan program kerja kesiswaan mencakup seluruh kegiatan yang bersifat akademik maupun non akademik, program kerjanya sebagai berikut: (a) Sinkronisasi kurikulum; (b) Pelaksanaan magang guru; (c) Pertukaran pelajar; (d) Penambahan jam belajar di bengkel; (e) Penambahan jam belajar persiapan unas; (f) Pelaksanaan seminar (Safety riding, Gerakan anti narkoba); (g) Ekstrakurikuler bakat, minat, dan jurusan.

Kemampuan yang dimiliki peserta didik selama menempuh pendidikan di SMK Negeri 5 Surabaya yaitu: (1) Pengalaman prakerin; (2) Pengalaman praktikum; (3) Berprestasi baik akademik maupun non akademik; (4) Konsep keseluruhan \& praktik tentang materi pada setiap jurusan; dan (5) Bagaimana mempunyai etika baik dalam menghadapi dunia kerja (bertanggungjawab \& disiplin waktu).

Hambatan dalam pelaksanaan sekolah 4 tahun yaitu: (1) Perbedaan karakter setiap peserta didik dalam menerima proses pembelajaran; (2) Pernah terdapat ada guru yang belum disiplin; (3) Peralatan kecil di bengkel masih ada yang belum lengkap karena dibawa peserta didik pulang; dan (4) Belum tersedianya kipas angin di seluruh Ruang Pendidikan. Sedangkan dalam hambatan yang ditemukan, pihak sekolah dan peserta didik mempunyai alternatif pemecahan masalah yang dilakukan, yaitu: (1) Senantiasa mengontrol proses pembelajaran dari pagi-sore dengan adanya beberapa petugas satpam; (2) Memberi peringatan dan segera melakukan mutasi kepada guru yang belum disiplin dalam bekerja; (3) Melengkapi peralatan dan sarana yang belum ada; dan (4) Bertindak tegas kepada peserta didik yang belum disiplin dan tanggung jawab.

\section{PEMBAHASAN}

Program sekolah 4 tahun yang dimiliki SMK Negeri 5 Surabaya merupakan program yang dilakukan sejak awal berdirinya sekolah ini. Program ini merupakan proyek perintis pembangunan yang digagas oleh Presiden Soeharto. Pada mulanya saat presiden mendirikan proyek tersebut, hanya ada 8 sekolah di Indonesia yang menjalankan program pendidikan selama 4 tahun. 8 sekolah tersebut dari Jakarta, Semarang, Yogyakarta, Surabaya, Makassar, Bandung, Pekalongan, dan Temanggung. 


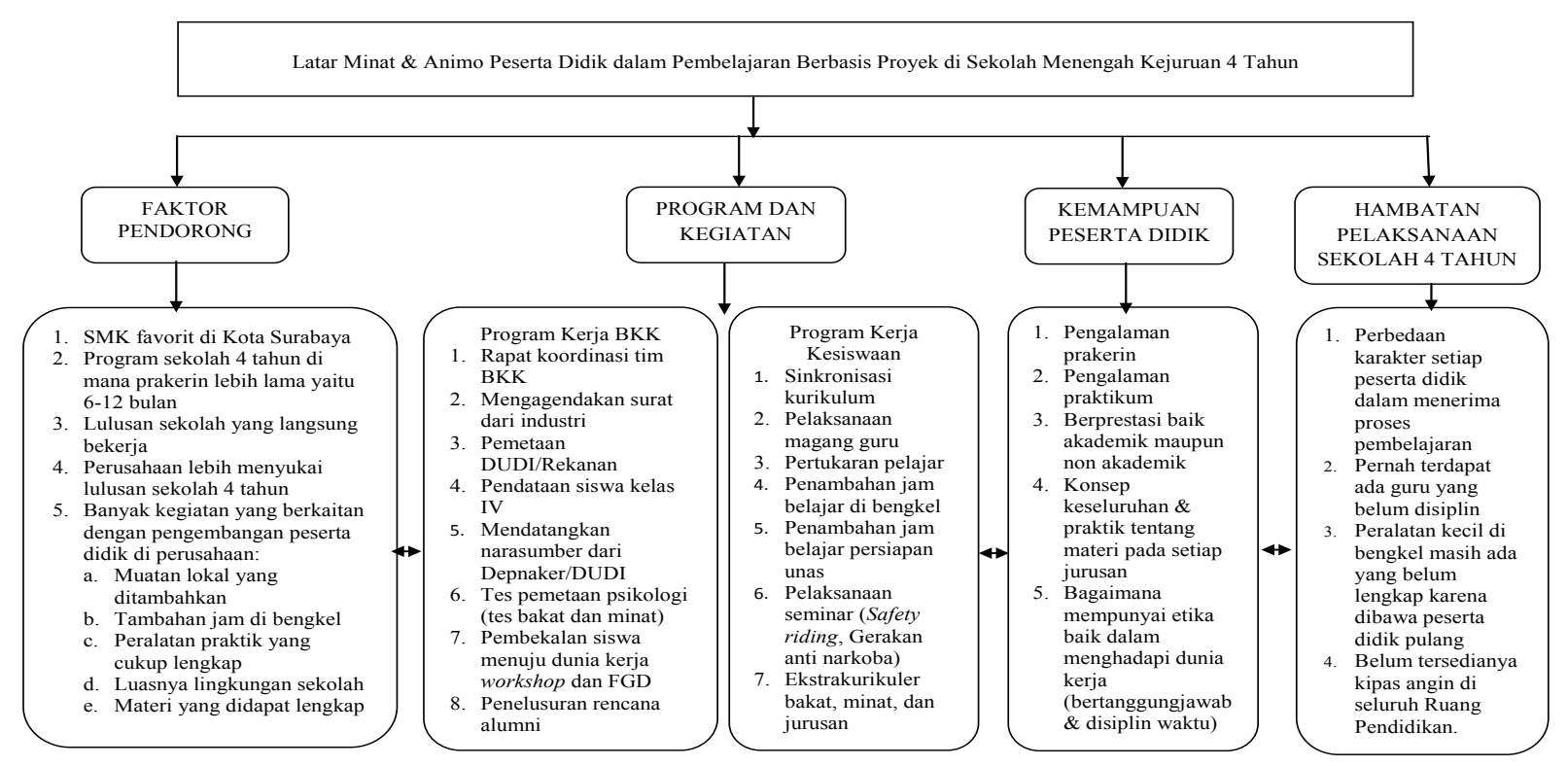

Gambar Ringkasan Latar Minat \& Animo Peserta Didik dalam Pembelajaran Berbasis Proyek di Sekolah Menengah Kejuruan 4 Tahun

Keunikan dari sekolah 4 tahun ini adalah pelaksanaan prakerin dilakukan pada kelas IV sehingga tidak menganggu proses belajar mengajar di kelas I-III, sedangkan untuk SMK 3 tahun pelaksanaan prakerinnya diletakkan di kelas II dan menganggu proses belajar mengajar di kelas II karena pelajaran yang diberikan harus dirapatkan pada awal semester I sehingga membebankan peserta didik di awal semester. Berdasarkan keunikan tersebut maka animo peserta didik yang mendaftar di sekolah tersebut cukup banyak walau mereka mengetahui jika SMK Negeri 5 Surabaya masa pendidikannya lebih lama 1 tahun dari sekolah lain. Pernyataan tersebut sesuai dengan teori animo yang dikemukakan oleh Suciani \& Setyadin (2008: 55), bahwa animo siswa adalah hasrat dan keinginan yang kuat dari diri siswa untuk melakukan sesuatu demi tercapainya keinginan dan cita-cita yang diinginkannya. Animo peserta didik pada sekolah 4 tahun ini sangatlah tinggi. Animo tersebut dapat dilihat pada pendaftar sekolah setiap tahunnya. Animo seseorang selalu diikuti dengan minat pada suatu hal, sesuai dengan yang disampaikan oleh Djaali (2012:121) minat adalah rasa lebih suka dan rasa ketertarikan pada suatu hal atau aktivitas, tanpa ada yang menyuruh. Semakin kuat atau dekat hubungan tersebut, semakin besar minatnya, berdasarkan besarnya minat peserta didik terhadap sekolah ini maka dalam memilihnya peserta didik mempertimbangkan keuntungan-keuntungan yang diperoleh jika bersekolah di SMK Negeri 5 Surabaya seperti yang diungkapkan bahwa faktor pendorong peserta didik memilih SMK Negeri 5 Surabaya ini adalah: (1) SMK favorit di Kota Surabaya; (2) Program sekolah 4 tahun di mana prakerin lebih lama yaitu 6-12 bulan; (3) Lulusan sekolah yang langsung bekerja; (4) Perusahaan lebih menyukai lulusan sekolah 4 tahun; (5) Banyak kegiatan yang berkaitan dengan pengembangan peserta didik di perusahaan: (a) Muatan lokal yang ditambahkan; (b) Tambahan jam di bengkel; (c) Peralatan praktik yang cukup lengkap; (d) Luasnya lingkungan sekolah; dan (e) Materi yang didapat lengkap.

Berdasarkan faktor pendorong diatas maka pelaksanaan program sekolah 4 tahun ini memiliki banyak keuntungan. Keuntungan tidak hanya berasal dari pihak intern sekolah namun juga pihak ekstern sekolah. Pihak intern sekolah meliputi peserta didik, orangtua peserta didik, dan seluruh warga sekolah sedangkan pihak ekstern sekolah diantaranya perusahaan yang bekerjasama dengan sekolah dan masyarakat umum. Banyaknya pihak yang merasa diuntungkan menandakan bahwa sekolah tersebut telah memberikan kepuasan pelanggan pada pengguna jasa pendidikan. Kepuasaan adalah respon balik dari pengguna layanan jasa pendidikan yang keinginannya telah dipenuhi. Menurut Benty \& Gunawan (2015: 34) kepuasan pelanggan jasa pendidikan adalah peserta didik, orangtua peserta didik, kepala sekolah, guru, dan lembaga luar yang bekerjasama dengan sekolah. Kepuasaan pelanggan diukur dari kesenjangan antara harapan dan persepsi pelanggan terhadap pelayanan yang akan diterima. Kepuasaan pelanggan ditentukan oleh keyakinan atas kinerja sekolah dalam mengelola peserta didik sehingga 
menghasilkan lulusan yang dibutuhkan perusahaan. Kepuasaan masyarakat terhadap kinerja sekolah ditunjukkan dengan merekomendasikan sekolah ini kepada masyarakat luas karena terbukti lulusannya dapat langsung bekerja.

Pembuatan program kerja pada setiap organisasi atau lembaga pendidikan merupakan upaya untuk pencapaian tujuan sebuah lembaga pendidikan khususnya sekolah. Program kerja diwujudkan dalam bentuk program dan kegiatan yang dilaksanakan oleh sekolah. Semakin baik program kerja yang direncanakan maka semakin baik pula dalam menunjang produktivitas input sebuah sekolah. Penyusunan program kerja SMK Negeri 5 Surabaya dibuat berdasarkan kebutuhan kurikulum dan perusahaan selaku pengguna jasa layanan pendidikan. Sependapat dengan yang disampaikan oleh Benty \& Gunawan (2015: 144) program kerja adalah suatu rencana kegiatan dan suatu organisasi yang terarah, terpadu, dan tersistematis yang dibuat untuk rentang waktu yang telah ditentukan oleh suatu organisasi. Program kerja merupakan pedoman dasar untuk sebuah lembaga atau organisasi dalam menjalankan sebuah visi misi. Jika pedoman dasar tidak mampu mencerminkan visi misi sebuah lembaga maka lembaga tersebut akan mendapatkan kesulitan dalam mencapai tujuan yang telah ditentukan. Dalam menyusun program kerja, kepala sekolah harus kreatif dan tanggap dengan keadaan sekolah. Keadaan sekolah yang diamati mencakup keseluruhan yaitu dari personel sekolah hingga sarana dan prasarana yang tersedia karena kedua hal tersebut saling berkaitan dalam mencapai tujuan lembaga pendidikan. Program kerja dibuat untuk mengembangkan dan memperbaiki kegiatan yang sebelumnya dianggap belum maksimal. Program kerja harus dapat mewujudkan tujuan lembaga pendidikan ke arah yang lebih baik sesuai dengan tuntutan zaman. Program dan kegiatan yang dilaksanakan sekolah sudah baik karena mampu mengembangkan potensi peserta didik dan memberikan tenaga kerja profesional untuk perusahaan.

Program kerja yang diselenggarakan sekolah sekaligus menjadi pembeda dari SMK lain adalah adanya kegiatan sinkronisasi kurikulum dan kegiatan prakerin yang dilaksanakan selama 6-10 bulan di kelas IV. Sinkronisasi kurikulum merupakan kegiatan penyelarasan antara mata pelajaran umum dan produktif dengan kebutuhan di sebuah industri. Kegiatan sinkronisasi kurikulum sangat bermanfaat bagi perkembangan diri peserta didik karena ilmu yang didapat peserta didik dapat diterapkan di industri dan tidak ada mata pelajaran yang tidak sesuai. Sehingga ketika lulus peserta didik sudah terbiasa dengan lingkungan kerja karena sudah mengetahui sedikit banyak terkait pengetahuan yang ada di lingkungan kerja. Program kerja di SMK terdiri dari program kerja sekolah secara umum, kesiswaan, dan Bursa Kerja Khusus (BKK). Program kerja BKK inilah yang membedakan antara SMA dengan SMK. Program kerja BKK lebih mengutamakan pada kegiatan terkait output peserta didik nantinya, peningkatan skill peserta didik dalam menghadapi dunia kerja.

Hasil dari pemakai jasa layanan pendidikan seperti di sekolah yaitu output yang mempunyai kemampuan dan kompetensi yang memadai. Kemampuan adalah keahlian seseorang dalam menyelesaikan beberapa tugas atau pekerjaan serta meningkatnya skill individu. Menurut Ivancevich (2007: 85) kemampuan adalah bakat seseorang untuk melakukan tugas mental atau fisik. Sedangkan menurut Robbin (2001: 46) kemampuan yaitu suatu kapasitas individu untuk mengerjakan berbagai tugas dalam suatu pekerjaan.

Lulusan pendidikan kejuruan lebih diprioritaskan untuk bekerja karena saat sekolah mereka tidak hanya diberi materi umum seperti SMA tetapi juga dibekali kemampuan dan pengetahuan terkait materi kejuruan sesuai dengan jurusan yang dipilih. Karena pada dasarnya lulusan SMK telah mampu untuk mandiri dalam menghadapi dunia kerja. Lulusan SMK Negeri 5 Surabaya selain skill juga mengutamakan etika dalam bekerja. Kemampuan yang didapat saat di sekolah akan diterapakan ke dalam dunia luar yaitu masyarakat dan dunia kerja. Kemampuan peserta didik di SMK Negeri 5 Surabaya diukur melalui kegiatan sertifikasi keahlian yang dilaksanakan sekolah. Pada kelas XII di akhir semester, peserta didik melaksanakan kegiatan tersebut berdasarkan masing-masing jurusan. Dalam kegiatan tersebut, peserta didik melakukan praktik terkait materi yang telah didapatkan selama 3 tahun sesuai dengan jurusan yang dipilih. Hasil dari kegiatan ini adalah sertifikat yang nantinya dapat dipergunakan saat peserta didik akan bekerja. Sertifikasi tersebut merupakan syarat dan biasanya perusahaan lebih mengutamakan peserta didik yang memiliki sertifikat tersebut. 
Setiap kegiatan maupun program yang telah dilaksanakan pasti mengalami hambatan saat prosesnya. Penyelenggaraan sekolah 4 tahun juga menemukan hambatan yang dikemukakan oleh warga sekolah. Hambatan adalah kesenjangan (ketidaksesuaian) antara kenyataan dengan keinginan. Hambatan terjadi karena kurang puasnya pengguna jasa pendidikan terhadap sesuatu yang telah dilaksanakan oleh sekolah. Sependapat dengan Benty \& Gunawan (2015: 37), secara umum keluhan yang dikemukakan seseorang berdasarkan kurang atau tidak terpenuhinya kebutuhan dan keinginan masing-masing. (1) tidak sesuai harapan dengan kenyataan yang dialami; (2) ketidakpuasan dalam pelayanan selama proses menikmati jasa; (3) perilaku personil kurang memuaskan; (4) suasana dan kondisi fisik lingkungan tidak menunjang; (5) ongkos terlalu tinggi, karena jarak, waktu, dan harga terlalu tinggi; dan (6) promosi tidak sesuai dengan kenyataan.

Hambatan dalam pelaksanaan sekolah 4 tahun yaitu: (1) Perbedaan karakter setiap peserta didik dalam menerima proses pembelajaran; (2) Pernah terdapat ada guru yang belum disiplin; (3) Peralatan kecil di bengkel masih ada yang belum lengkap karena dibawa peserta didik pulang; dan (4) Belum tersedianya kipas angin di seluruh Ruang Pendidikan. Sedangkan dalam hambatan yang ditemukan, pihak sekolah mempunyai alternatif pemecahan masalah yang dilakukan, yaitu: (1) Senantiasa mengontrol proses pembelajaran dari pagi-sore dengan adanya beberapa petugas satpam; (2) Memberi peringatan dan segera melakukan mutasi kepada guru yang belum disiplin dalam bekerja; (3) Melengkapi peralatan dan sarana yang belum ada; dan (4) Bertindak tegas kepada peserta didik yang belum disiplin dan tanggung jawab. Solusi yang dilaksanakan sesuai dengan pendapat Kotler dalam Benty \& Gunawan (2015: 34-35) mengemukakan tentang upaya peningkatan kepuasaan pelanggan jasa pendidikan melalui kualitas jasa pendidikan dapat dengan menggunakan pendekatan yaitu: (1) memperkecil kesenjangan yang terjadi antara pemimpin sekolah dan pelanggan jasa pendidikan; (2) pemimpin sekolah harus mampu membangun komitmen bersama untuk membuat visi sekolah dalam bentuk perbaikan proses jasa pendidikan; (3) pemimpin sekolah harus mampu memberikan kesempatan kepada pelanggan jasa pendidikan untuk menyampaikan keluhan; dan (4) pemimpin sekolah harus mampu mengembangkan dan menerapkan pemasaran jasa pendidikan secara bertanggung jawab dan proaktif sesuai situasi pemasaran jasa pendidikan yang dihadapi.

\section{KESIMPULAN DAN SARAN}

\section{Kesimpulan}

SMK Negeri 5 Surabaya sebagai sekolah menengah kejuruan yang menempuh pendidikan selama 4 tahun dapat menarik animo dan minat peserta didik untuk mendaftar di sekolah tersebut. Walaupun masyarakat dan peserta didik telah mengetahui bahwa sekolah ini pendidikannya lebih lama 1 tahun daripada sekolah lain tetapi animo peserta didik yang memilih sekolah ini cukup banyak. Keunikan dari sekolah 4 tahun ini adalah pelaksanaan prakerin dilakukan pada tingkat akhir yaitu kelas IV selama 6-10 bulan. Tujuan diadakan pada kelas akhir supaya nanti saat peserta didik telah menyelesaikan prakerin di perusahaan, perusahaan yang menyukai kinerja peserta didik tersebut dapat langsung merekrut tanpa harus melamar lagi. Karena banyak perusahaan yang menyukai peserta didik yang bersekolah selama 4 tahun ini. Kelebihan lain yang dimiliki yaitu perusahaan yang bekerjasama dengan sekolah termasuk dalam perusahaan yang sudah terkenal dan merupakan perusahaan yang besar, sehingga dalam penempatan prakerin, sekolah tidak hanya menempatkan peserta didik pada daerah Surabaya saja melainkan meliputi daerah lain seperti Gresik, Sidoarjo, Jawa Tengah, Jawa Barat, dan luar Pulau Jawa. Walau memiliki banyak keunikan dan kelebihan tetapi sekolah sebagai lembaga jasa pendidikan tetap menemukan hambatan dalam penyelenggaraan pendidikan. Hambatan yang ditemukan pada sekolah 4 tahun ini adalah masih belum lengkapnya sarana prasarana yang menunjang pembelajaran peserta didik seperti belum terdapatnya kipas angin di seluruh Ruang Pendidikan. Sedangkan sarana yang belum lengkap adalah peralatan kecil yang ada di bengkel karena sebagian hilang dibawa pulang oleh peserta didik. Sehingga sekolah dituntut untuk lebih tegas terhadap sikap peserta didik yang belum bertanggungjawab. 


\section{Saran}

Berdasarkan kesimpulan di atas terdapat beberapa saran untuk penelitian selanjutnya yang relevan dengan subjek penelitian ini: (1) Kepala SMK Negeri 5 Surabaya, pembelajaran pendidikan kejuruan selama 4 tahun ini sudah sangat bagus untuk lingkup SMK namun diharapkan selalu meningkatkan program dan kegiatan yang dilaksanakan, penambahan sarana dan prasarana yang belum ada sehingga dapat memenuhi kebutuhan peserta didik di sekolah; (2) Peserta Didik, adanya pendidikan kejuruan selama 4 tahun ini diharapkan dapat meningkatkan kedisiplinan setiap individu untuk selalu semangat dan bersungguh-sungguh dalam menerima proses pembelajaran di sekolah untuk bekal saat sudah lulus nanti; (3) Orangtua Peserta Didik, adanya pendidikan kejuruan selama 4 tahun ini diharapkan dapat mengarahkan orangtua untuk selalu memperhatikan dan mengamati perkembangan anaknya supaya tetap menjalankan peraturan yang ada di sekolah, (4) Ketua Jurusan Administrasi Pendidikan, disarankan agar hasil penelitian ini dapat dijadikan sebagai salah satu referensi tema penelitian mahasiswa yang berkaitan dengan program unggulan sekolah dalam mengembangkan proses pembelajaran yang dilaksanakan setiap lembaga pendidikan, serta supaya tetap menjaga kerja kerjasama yang baik dengan sekolah sebagai lokasi penelitian; dan (5) Peneliti Lain, dapat melanjutkan penelitian pada berbagai aspek yang belum terungkap tentang kurikulum dalam pendidikan kejuruan 4 tahun ini, supaya lebih banyak lagi masyarakat yang mengetahui adanya sistem pembelajaran 4 tahun dan juga mengetahui beberapa keuntungan yang didapat dari sistem pembelajaran tersebut.

\section{DAFTAR RUJUKAN}

Benty, D.D.N \& Gunawan, I. 2015. Manajemen Hubungan Sekolah Dan Masyarakat. Malang: UM Press.

Djaali. 2012. Psikologi Pendidikan. Jakarta: Bumi Aksara.

Ivancevich. 2007. Perilaku dan Manajemen Organisasi, Jilid I, Edisi Ketujuh. Jakrata: Erlangga.

Suciani, Y \& Setyadin, B. 2008. Analisis Animo Siswa SD/MI Dalam Partisipasi Memilih SLTP Di SD/MI Se-

Kota Blitar. Jurnal Ilmu Pendidikan, 21 (1): 51-58.

Udaya, J. 2001. Teori Organisasi: Struktur, Desain, dan Aplikasi. Jakarta: Arcan. 